\title{
A HYBRID BANKING WEBSITES QUALITY EVALUATION MODEL USING AHP AND COPRAS-G: A TURKEY CASE
}

\author{
Fatih ECER \\ International Trade and Finance, Faculty of Economics and Administrative Sciences, ANS Campus, \\ Afyon Kocatepe University, 03030 Afyonkarahisar, Turkey
}

Received 10 June 2013; accepted 01 December 2013

\begin{abstract}
The quality of websites can directly influence bank's effectiveness. Therefore, the effective evaluation of the quality of bank websites is a point of concern for customers, owners, and researchers. The primary goal of the study is to propose a hybrid model of AHP and COPRAS-G methods for evaluating the website quality of banks. Furthermore, this study sheds light on understanding weights of evaluation criteria related to quality of bank websites. In this study, the weights of the evaluation criteria are computed by AHP method. Next, COPRAS-G is used to assess the quality levels of the websites and to rank them. A case study of evaluating the quality of bank websites of seventeen banks in Turkey is used to demonstrate the applicability and the effectiveness of this model. Empirical findings show that banks in Turkey utilize the Internet to its full potential to improve their websites. Furthermore, Garanti Bankasi has the best overall performance, followed by TEB, and Ziraat Bankasi. Additionally, the top-five evaluation criteria in order of importance are relevance, richness, understandability, navigability, and response time. Overall, the results show that this model provides a comprehensive and systematic approach that quantitatively measures a website's quality.
\end{abstract}

Keywords: website quality, COPRAS-G, AHP, banking, grey system theory.

JEL Classification: C44, C65, G21.

\section{Introduction}

Nowadays, many firms will switch their business models from the physical to the virtual market. The physical distribution of goods through banks, stores, bookstores, mail and newspapers, among others, is gradually moving to the virtual market (Lee et al. 2011). A firm's website represents their public face to the world. Websites are frequently the first point of contact between a firm and their customers (Gregg, Walczak 2010). Effective use of a website

Corresponding E-mail:

fecer@aku.edu.tr 
can enhance public recognition, build brand image, improve service to existing customers, supply information to potential employees, and reduce the time and effort required to acquire profitable new customers (Chou, Cheng 2012).

Huge advancements in information technology have extremely affected the financial services industry, as is evident in the development of online banking in recent years (Lee et al. 2011). Online banking can be defined as the services which allow customers to conduct financial transactions on a secure website operated by a retail or virtual bank, credit union or building society. However, online banking mostly depends on the quality of service delivered by the website. As building long term customer relationships generate positive customer value on the Internet, effective evaluation and monitoring of website quality have become prerequisites for profitable online banking (Bauer et al. 2005; Jayawardhena 2004; Jun, Cai 2001; Lee, Chung 2009; Kaya, Kahraman 2011). In other words, the higher the bank website's quality, the higher the bank's effectiveness is (DeLone, McLean 2003).

In line with the many potential criteria must be considered in the evaluation procedure of website quality, the problem is a kind of multi-criteria decision making (MCDM) problems. MCDM is capable of dealing with the multiple dimensions of evaluation problems and is a rapidly developing area in operational research and management science (Turskis et al. 2009; Shee, Wang 2008). The complete MCDM process involves the following basic elements: criteria, preference structure, alternatives, and performance values. While the final decision will be made based on the performance of alternatives, evaluation criteria and preference structure are key influential factors and should be prepared in advance. In order to obtain the evaluation criteria and preference structure, a hierarchical analysis must be carried out (Shee, Wang 2008). Over the past decades there had been a large number of refined MCDM methods developed and they differ from each other in the required quality and quantity of additional information, the methodology used, the user-friendliness, the sensitivity tools used, and the mathematical properties they verify (Zavadskas, Turskis 2011). Despite the fact that many attempts have been made to address website evaluation for different website categories, there is no universally accepted method or technique for website evaluation. Previous studies of website evaluation have provided a comprehensive and systematic approach. Different techniques have been employed to evaluate websites using subjective approaches based on individual preferences, such as the Analytic Hierarchy Process (AHP) (e.g. Lee, Kozar 2006; Shee, Wang 2008), Fuzzy AHP (FAHP) (e.g. Büyüközkan, Ruan 2007), Fuzzy Analytic Network Process (FANP) (e.g. Chou, Cheng 2012), Fuzzy TOPSIS (e.g. Büyüközkan, Ruan 2007; Law 2007), PROMETHEE (e.g. Bilsel et al. 2006), ELECTRE (e.g. Kaya, Kahraman 2011), Decision-Making Trial and Evaluation Laboratory (DEMATEL) (e.g. Tsai et al. 2010), Fuzzy VIKOR (e.g. Büyüközkan et al. 2007), and content analysis (e.g. Wan 2002; Cai et al. 2004; Baloglu, Pekcan 2006; Kasli, Avcikurt 2008). For example, Chou and Cheng (2012) aimed to build a hybrid approach that combines the FANP and fuzzy VIKOR for evaluating website quality of the top-four certified public accountant firms in Taiwan. They found that the top-five criteria to evaluate website quality are richness, understandability, assurance, relevance, and reliability. Tsai et al. (2010) proposed a hybrid model for evaluating national park websites in Taiwan. The authors first applied 
the DEMATEL to cope with the interdependencies between evaluation criteria. Next, they used the ANP to compute weights for each criterion. Finally, they used the VIKOR to rank websites. Büyüközkan et al. (2007) aimed to measure the e-learning websites' performance. They investigated 10 worldwide and 11 locally successful websites according to seven criteria with the Fuzzy VIKOR method. Lee and Kozar (2006) applied AHP to evaluate electronics and travel websites. The authors identified the different weight of each website quality factor and priority of alternative websites across e-business domains and between stakeholders. Büyüközkan and Ruan (2007) used Fuzzy AHP and Fuzzy TOPSIS to rank 13 Turkish government websites with respect to six criteria. Kaya and Kahraman (2011) used an integrated FAHP-ELECTRE approach for developing e-banking website quality assessment. In the proposed approach, the weights of the evaluation criteria are generated by a FAHP method. Next, fuzzy ELECTRE is used to assess the quality levels of the websites. In the last step, a fuzzy dominance relation approach is used to rank the alternatives. Cai et al. (2004), Baloglu and Pekcan (2006) and Kasli and Avcikurt (2008) utilized content analysis to analyze the websites of tour operators, hotels, and tourism departments at universities, respectively, using a measurement variable of yes/no.

The AHP method was developed by Saaty (1980) to provide an overarching view of the complex relationships inherent in the problem and helps the decision makers assess whether evaluation criteria are of the same order of magnitude (Lee, Kozar 2006). Recently, a compromise ranking method, namely the COmplex PRoportional ASsessment of alternatives with Grey relations (COPRAS-G) has been presented as an applicable method for implementation within MCDM (e.g. Datta et al. 2009; Chatterjee, Chakraborty 2012; Bitarafan et al. 2012; Aghdaie et al. 2013).

In this vein, the paper aims to propose a hybrid model that combines AHP and COPRAS-G for evaluating and ranking the quality of bank websites. Till date, COPRAS-G method has very limited applications in the economic field. Using the information systems (IS) success model (DeLone, McLean 2003), this paper explores information quality, service quality, and system quality as main evaluation criteria. For the determination of the weights of main criteria and sub-criteria, AHP method is used since it is based on pairwise comparisons. Then, the weights obtained through AHP method are combined with COPRAS-G to assess and rank the quality of bank websites. Furthermore, in order to verify the usefulness of this hybrid model, a case study of the top seventeen public and private bank websites in Turkey is offered. The findings of this paper can help banks for a clear picture of their websites' quality level and then prioritize the strategies for improvement. Additionally, this paper will be a valuable contribution to achieving desired quality levels. Hence, this hybrid model represents an effective tool for evaluating bank websites.

The rest of this paper is organized as follows. First, website quality is reviewed, AHP and COPRAS-G methods are explained in detail in Section 2. An illustrating example is given and the empirical results are examined in Section 3. Finally, the conclusion is drawn out in the last section. 


\section{Website quality}

Awareness of quality issues has affected every sector in recent years. Quality is a characteristic of a product or service that reflects how well it meets the needs of its consumers. On the other hand, dimensions of web quality may be different from the traditional practice of quality in that web quality to be a complex thing and multi-dimensional measurement in nature (Chou, Cheng 2012; Aladwani, Palvia 2002). Website quality refers to the attributes of a website that contribute to its usefulness to consumers (Gregg, Walczak 2010). Prior website quality researches have identified numerous website quality dimensions. Table 1 gives a summary of the dimensions used in website quality evaluation models in prior studies.

Table 1. Website evaluation studies

\begin{tabular}{|c|c|c|c|}
\hline Year & Authors & $\begin{array}{l}\text { No. } \\
\text { citiation }\end{array}$ & Dimensions \\
\hline 2000 & Liu and Arnett & 1001 & Design quality, system use, playfulness, information, service \\
\hline \multirow{3}{*}{2001} & Smith & 118 & $\begin{array}{l}\text { Information (content, services, privacy, orientation to website, } \\
\text { currency, metadata, accuracy, external recognition), ease of use } \\
\text { (accessibility, design, links, feedback mechanisms, navigability) }\end{array}$ \\
\hline & Jun and Cai & 328 & Customer service, product, online systems \\
\hline & $\begin{array}{l}\text { Barnes } \\
\text { and Vidgen }\end{array}$ & 282 & Information, usability, service interaction \\
\hline \multirow{6}{*}{2002} & $\begin{array}{l}\text { Agarwal } \\
\text { and Venkatesh }\end{array}$ & 551 & $\begin{array}{l}\text { Promotion, emotion, ease of use, content, made for the } \\
\text { medium }\end{array}$ \\
\hline & Koufaris & 1339 & $\begin{array}{l}\text { Perceived ease of use, perceived usefulness, perceived control, } \\
\text { shopping enjoyment, concentration }\end{array}$ \\
\hline & Loiacono et al. & 42 & $\begin{array}{l}\text { Entertainment, ease of use, complementary relationship, } \\
\text { usefulness }\end{array}$ \\
\hline & $\begin{array}{l}\text { Ranganathan } \\
\text { and Ganapathy }\end{array}$ & 656 & Security, privacy, information, design. \\
\hline & Palmer & 1036 & $\begin{array}{l}\text { Interactivity, information and content, download speed, } \\
\text { navigation and organization, responsiveness }\end{array}$ \\
\hline & $\begin{array}{l}\text { Torkzadeh } \\
\text { and Dhillon }\end{array}$ & 411 & $\begin{array}{l}\text { Online payment, trust, product choice, shipping errors, } \\
\text { shopping travel }\end{array}$ \\
\hline \multirow[b]{2}{*}{2003} & $\begin{array}{l}\text { Delone and } \\
\text { McLean }\end{array}$ & 3472 & System, information, service \\
\hline & Wu et al. & 261 & $\begin{array}{l}\text { Privacy, impartiality, enjoyment, user empowerment, visual } \\
\text { appearance, information, technical support, navigation, } \\
\text { cognitive outcomes, organization of information, credibility }\end{array}$ \\
\hline \multirow{4}{*}{2004} & $\begin{array}{l}\text { Delone } \\
\text { and McLean }\end{array}$ & 470 & $\begin{array}{l}\text { System, information, satisfaction, individual impact, } \\
\text { organizational impact, use }\end{array}$ \\
\hline & Jayawardhena & 108 & Trust, website interface, attention, access, credibility \\
\hline & Kim and Stoel & 148 & $\begin{array}{l}\text { Ease of understanding, relative advantage, trust, tailored } \\
\text { communication, online completeness, visual appeal, } \\
\text { innovativeness, emotional appeal, consistent image, intuitive } \\
\text { operations, information, response time }\end{array}$ \\
\hline & Iwaarden et al. & 137 & Assurance, reliability, responsiveness, tangibles, empathy \\
\hline
\end{tabular}


Continued Table 1

\begin{tabular}{|c|c|c|c|}
\hline Year & Authors & $\begin{array}{c}\text { No. } \\
\text { citiation }\end{array}$ & Dimensions \\
\hline \multirow{2}{*}{2005} & Yang et al. & 352 & $\begin{array}{l}\text { Privacy/security, usefulness of content, accessibility, } \\
\text { information, usability, interaction }\end{array}$ \\
\hline & Bauer et al. & 131 & $\begin{array}{l}\text { Transaction support, basic services, cross-buying service, } \\
\text { added values, responsiveness, security and trust, }\end{array}$ \\
\hline \multirow{3}{*}{2006} & $\begin{array}{l}\text { Barnes } \\
\text { and Vidgen }\end{array}$ & 87 & Trust, information, usability, empathy, design \\
\hline & Lee and Kozar & 153 & $\begin{array}{l}\text { Reputation, security, understandability, price savings, empathy, } \\
\text { reliability, responsiveness, navigability, response time, } \\
\text { relevance, telepresence, awareness, personalization, currency }\end{array}$ \\
\hline & Moustakis et al. & 14 & $\begin{array}{l}\text { Design and structure, navigation, appearance and multimedia, } \\
\text { uniqueness, content }\end{array}$ \\
\hline \multirow[t]{2}{*}{2007} & Ahn et al. & 237 & $\begin{array}{l}\text { Perceived ease of use, service, playfulness, perceived usefulness, } \\
\text { information, attitude toward use, behavioral intention to use, } \\
\text { system }\end{array}$ \\
\hline & Loiacono et al. & 209 & Usefulness, ease of use, entertainment, trust, and response time \\
\hline 2008 & Bai et al. & 125 & Usability, customer satisfaction, functionality \\
\hline \multirow{3}{*}{2009} & Sun and Lin & 44 & $\begin{array}{l}\text { Familiarity, ease of use, trust, use of time, communication, } \\
\text { confidence, security, proficiency, past experience, practicality, } \\
\text { information }\end{array}$ \\
\hline & $\begin{array}{l}\text { Swaid } \\
\text { and Wigand }\end{array}$ & 35 & $\begin{array}{l}\text { Information quality, website usability, reliability, } \\
\text { responsiveness, assurance, personalization }\end{array}$ \\
\hline & Liang and Chen & 23 & Information, system and service \\
\hline \multirow[t]{2}{*}{2010} & $\begin{array}{l}\text { Rolland } \\
\text { and Freeman }\end{array}$ & 11 & $\begin{array}{l}\text { Ease of use, information content, fulfillment reliability, } \\
\text { security/privacy, customer service }\end{array}$ \\
\hline & $\begin{array}{l}\text { Kaya } \\
\text { and Kahraman }\end{array}$ & 17 & Costumer service, information, product \\
\hline \multirow[t]{4}{*}{2011} & Hur et al. & 2 & Information, interaction, design \\
\hline & Islam and Tsuji & 4 & Accessibility, Information, design, \\
\hline & Lee et al. & 14 & Perceived usefulness, perceived ease of use, offline trust \\
\hline & $\begin{array}{l}\text { Chou } \\
\text { and Cheng }\end{array}$ & 4 & Richness, understandability, assurance, relevance, reliability \\
\hline 2012 & Mittal et al. & - & $\begin{array}{l}\text { Load time, response time, mark-up validation, broken link, } \\
\text { accessibility error, size, page rank, frequency of update, traffic } \\
\text { and design }\end{array}$ \\
\hline 2013 & Zech et al. & - & $\begin{array}{l}\text { Clarity, ease of navigation, interactivity, usefulness, currency, } \\
\text { accuracy, attractiveness }\end{array}$ \\
\hline
\end{tabular}

\subsection{Dimensions of web quality}

DeLone and McLean's IS success model consists of the following quality factors: information quality, service quality, and system quality. The three quality factors of a website will play an important role in affecting the users' perceptions (Cao et al. 2005). The details of each quality factor are described below. 


\subsection{Information quality}

According to Chiou et al. (2010), information quality is the second most used factor in IS studies (82\%). Information quality means the quality of the information produced and delivered by a system and is considered to be a key factor affecting IS success. If the system does not provide the needed information, users will be dissatisfied and then leave it. Having useful and updated information, however, keeps a client visiting the website. To entice users to revisit, the website needs to provide with appropriate, complete, and clear information. Typical characteristics of information quality include relevance, understandability, richness, and currency (Lee, Kozar 2006; Bai et al. 2008; Roxas et al. 2000; DeLone, McLean 2003; Chou, Cheng 2012).

\subsubsection{Relevance}

Relevance includes relevant depth and scope and completeness of information. Different parts of the website should be designed to meet the needs of different groups of visitors, such as accountants, researchers, students, and local citizens (Lee, Kozar 2006; Cao et al. 2005; Tsai et al. 2010).

\subsubsection{Understandability}

Understandability includes easing of understanding and clearness of the information, such as documents written in plain language (Lee, Kozar 2006; Chou, Cheng 2012).

\subsubsection{Currency}

Currency involves updating of the information. Last update/review date is a critical way of notifying users of the currency of content (Smith 2001; Lee, Kozar 2006).

\subsubsection{Richness}

Richness refers to detailed level and scope of information content. In other words, information contained on the website is rich in content (Bilsel et al. 2006).

\subsection{Service quality}

Service quality refers to the overall support delivered by the website. That is, how well a delivered service level matches customer expectations. Service quality can be measured using reliability, assurance, and empathy (Ahn et al. 2007; Chou, Cheng 2012; Lee, Kozar 2006).

\subsubsection{Reliability}

Reliability involves the website's consistency of performance and dependability, focusing on whether the website is accurate, useful, and dependable. It is parallel to the technical function of the site such as speed and ability to quickly download information (Negash et al. 2003; Madu, C. N., Madu, A. A. 2002; Chou, Cheng 2012; Zeithaml 2002). 


\subsubsection{Assurance}

Assurance involves the ability of the personnel behind the firm's website to inspire trust and confidence, as well as display knowledge and courtesy (Madu, C. N., Madu, A. A. 2002; Chou, Cheng 2012; Zhou et al. 2009; Webb, H. W., Webb, L. A. 2004).

\subsubsection{Empathy}

Empathy refers to the extent to which a website provides caring, individualized information, and attention to users and has a user's best interest at heart, such as an easy way to sign up for the monthly newsletter and e-mail reminders before tax season (Cao et al. 2005; Carr 2003; Roxas et al. 2000; Chou, Cheng 2012).

\subsection{System quality}

System quality is not only a measure of the information processing system itself but also a technology use performance characteristic. High level of system quality may provide users with more convenience and privacy. System quality can be measured using accessibility, navigability, and response time (Ahn et al. 2007; Chou, Cheng 2012; Negash et al. 2003).

\subsubsection{Accessibility}

Accessibility evaluates whether information can be accessed efficiently and whether the site can be located using standard resource discovery tools. Accessibility is also the ability of the website to be accessed by disabled users (Smith 2001; Mohanty et al. 2007).

\subsubsection{Navigability}

Navigability measures how easy it is to navigate around the site, how easy it is to return to the home page of the site, how easy it is to find relevant information, how many links are required to get from one point in a site to another, and what search tools the site provides (Miranda-Gonzalez, Banegil-Palacios 2004; Smith 2001; Tsai et al. 2010).

\subsubsection{Response time}

Fast response time is important to increase system quality in that online users are unwilling to wait more than a few seconds for a response (Lee, Kozar 2006). In particular, the response time is to be desired minimum by online customers in the banking sector.

\section{Methodology}

Over the past two decades, the complexity of economic decisions has increased rapidly, thus highlighting the importance of developing and implementing sophisticated and efficient quantitative analysis methods for supporting and aiding economic decision making (Zavadskas, Turskis, 2011; Aghdaie et al. 2013). MCDM is an advanced field of operations research, provides decision makers and analysts with a wide range of methodologies, which 
are overviewed and well suited to the complexity of economic decision problems (Hwang, Yoon 1981; Zopounidis, Doumpos 2002; Figueira et al. 2005; Aghdaie et al. 2013). In this paper, a hybrid AHP and COPRAS-G model is proposed in order to evaluate the quality of bank websites. The detailed descriptions of these methods are elaborated in the following subsections.

\subsection{Analytic Hierarchy Process (AHP)}

As one of the most utilized MCDM methods, the AHP method was developed by Saaty (1980) (Gao, Hailu 2013; Ecer, Küçük 2008). AHP has many advantages. For example, AHP provides a measure of consistency in decision makers' judgments or preferences. AHP also allows decision makers to start from pairwise comparisons that are simple enough to work with and often are preferred by the decision makers (Gao, Hailu 2013). The basic steps of this method are as follows (Yu et al. 2011; Barker, Zabinsky 2011).

Step 1: Compose AHP structure. With the AHP, the objectives, evaluation criteria and alternatives are arranged in a hierarchical structure. Usually, a hierarchy has three levels such as goal, criteria, and alternatives.

Step 2: Establish a pairwise comparison matrix. In order to determine the weight of evaluation criteria, the second step is the pair comparison of criteria. The pairwise comparison matrix contains numerical judgments assigned to each criterion, sub-criterion, and alternative. In AHP, multiple pairwise comparisons are from a standardized comparison scale of nine levels shown in Table 2. Suppose that $C=\left\{C_{j}, j=1,2, \ldots, n\right\}$ be the set of evaluation criteria. Evaluation matrix can be gotten, in which every element $a_{i j}(i, j=1,2, \ldots, n)$ represents the weights of the evaluation criteria illustrated:

$$
A=\left[\begin{array}{cccc}
a_{11} & a_{12} & \cdots & a_{1 n} \\
a_{21} & a_{22} & \cdots & x_{2 n} \\
\vdots & \vdots & \cdots & \vdots \\
a_{n 1} & a_{n 2} & \cdots & a_{n n}
\end{array}\right],
$$

where $a_{i j}(i, j=1,2, \ldots, n)$ has complied with following condition:

$$
a_{i j}=\frac{1}{a_{j i}}, a_{i i}=1, a_{j i}>0 .
$$

Table 2. The fundamental scale of pairwise comparisons

\begin{tabular}{cl}
\hline Definition & \multicolumn{1}{c}{ Value } \\
\hline 1 & Equal importance \\
3 & Weak importance \\
5 & Essential importance \\
7 & Demonstrated importance \\
9 & Extreme importance \\
$2,4,6,8$ & Intermediate values \\
\hline
\end{tabular}


Step 3: Calculate the criteria weights. By the equation:

$$
A W=\lambda_{\max } W .
$$

The $\lambda_{\max }$ can be acquired. If the $\lambda_{\text {max }}$ is equal to $n$ and the rank of matrix $A$ is $n, A$ is consistent. In this case, the relative criteria can be discussed. The weight of each criterion will be calculated by normalizing any of the rows or columns of the matrix $A$.

Step 4: Test consistency. AHP must meet the requirement that the matrix $A$ is consistent. There are two parameters, consistency index $(C I)$ and consistency ratio $(C R)$. Both of them are defined as follows:

$$
\begin{gathered}
C I=\frac{\lambda_{\max }-n}{n-1} ; \\
C R=\frac{C I}{R I},
\end{gathered}
$$

where $R I$ is random index. For the different count of criteria, it has a different value demonstrated in Table 3. If $C R$ is less than 0.10 , the result can be accepted and the matrix $A$ is sufficient consistency. Otherwise, we have to return to step 1 and repeat again.

Table 3. The relationship between RI value and count of criterion

\begin{tabular}{ccccccccccc}
\hline$n$ & 1 & 2 & 3 & 4 & 5 & 6 & 7 & 8 & 9 & 10 \\
\hline$R I$ & 0 & 0 & 0.52 & 0.89 & 1.11 & 1.25 & 1.35 & 1.40 & 1.45 & 1.49 \\
\hline
\end{tabular}

\subsection{The COPRAS-G method}

In order to evaluate the overall efficiency of an alternative, it is necessary to identify evaluation criteria, to assess information relating to these criteria, and to develop methods for evaluating the criteria to meet the participant's needs. Decision analysis is concerned with the situation in which a decision maker has to choose among several alternatives by considering multiple evaluation criteria (Aghdaie et al. 2013). For this reason COmplex PRoportional ASsessment (COPRAS) method that was first announced by Zavadskas et al. (1994) can be applied. COPRAS method assumes direct and proportional dependences of the significance and utility degree of the available alternatives under the presence of mutually conflicting criteria. It considers the performance of the alternatives according to different evaluation criteria and the corresponding criteria weights. Finally, this method selects the best alternative considering both the ideal and the ideal-worst solutions (Chatterjee et al. 2011). This method has already been successfully applied to solve various problems in the field of construction, property management, etc. (Kaklauskas et al. 2006; Viteikiene, Zavadskas 2007; Banaitiene et al. 2008; Podvezko 2011; Chatterjee et al. 2011).

However, most of the MCDM problems cannot be determined or predicted by certain and exact attribute values, but it can be expressed in terms of fuzzy values or with values in some intervals. So, it becomes necessary to extend the applications from white numbers (crisp values) to grey numbers for real time applications. Grey number is basically a concept of Grey System Theory (GST) to deal with the insufficient and incomplete 
information (Chatterjee, Chakraborty 2012). The GST was introduced by Deng (1982) to supplement the limitations of using traditional statistical methods. Grey relational analysis (GRA) is useful for capturing the correlations between the reference factor and other factors which can be compared within a system (Deng 1988; Huang et al. 2008). One of the features of GRA is that both qualitative and quantitative relationships can be identified among complex factors with insufficient information. It also involves simple calculations; it requires smaller samples; a typical distribution of samples is not needed; the quantified outcomes from the grey relational grade do not result in contradictory conclusions about the qualitative analysis; and the grey relational grade model is a transfer functional model that is effective in dealing with discrete data (Cheng et al. 2010; Zavadskas et al. 2008).

Hence, Zavadskas et al. (2008) presented the main ideas of COPRAS-G method to deal with the problem of matching managers to construction projects. The idea of COPRAS-G method is based on the real conditions of decision making and applications of the GST. It uses a stepwise ranking and evaluating procedure of the alternatives in terms of significance and utility degree (Hashemkhani Zolfani et al. 2012a).

In recent years, the COPRAS-G method has been applied to the solution of complicated MCDM problems in social sciences. The recent developments of decision making models based on COPRAS-G method is listed below:

- Ginevičius and Podvezko (2008) evaluated of banks from the perspective of their reliability for customers;

- Datta et al. (2009) and Hashemkhani Zolfani et al. (2012a) used COPRAS-G method for employee selection;

- Bindu Madhuri et al. (2010) selected the best websites based on COPRAS-G;

- Sahu et al. (2012) and Hashemkhani Zolfani et al. (2012b) presented the evaluation and selection of suppliers;

- Aghdaie et al. (2013) used COPRAS-G method for market segment evaluation and selection;

- Tavana et al. (2013) applied COPRAS-G method to select the most suitable social media platform.

The procedure of the COPRAS-G method consists of the following steps (Zavadskas et al. 2008):

Step 1. Selection of the available set of the most important evaluation criteria, which describes alternatives. To apply COPRAS-G method, the type of evaluation criteria (maximizing or minimizing) is determined. The best values of minimizing criteria are the smallest values, while the largest values are the best for maximizing criteria.

Step 2. Constructing the decision making matrix $X$ :

$$
X=\left[\begin{array}{cccc}
{\left[s_{11} ; b_{11}\right]} & {\left[s_{12} ; b_{12}\right]} & \cdots & {\left[s_{1 m} ; b_{1 m}\right]} \\
{\left[s_{21} ; b_{21}\right]} & {\left[s_{22} ; b_{22}\right]} & \cdots & {\left[s_{2 m} ; b_{2 m}\right]} \\
\vdots & \vdots & \ddots & \vdots \\
{\left[s_{n 1} ; b_{n 1}\right]} & {\left[s_{n 2} ; b_{n 2}\right]} & \cdots & {\left[s_{n m} ; b_{n m}\right]}
\end{array}\right] ; i=1,2, \ldots, m ; j=1,2, \ldots, n,
$$

where $s_{i j}$ the smallest value, $b_{i j}$ the biggest value. 
Step 3. Determining weights of the evaluation criteria $q_{j}$.

Step 4. Normalization of the decision making matrix $\bar{X}$. The normalized values of this matrix are calculated as:

$$
\overline{s_{i j}}=\frac{2 s_{i j}}{\sum_{j=1}^{n} s_{i j}+\sum_{j=1}^{n} b_{i j}} ; \overline{b_{i j}}=\frac{2 b_{i j}}{\sum_{j=1}^{n}\left(s_{i j}+b_{i j}\right)} .
$$

In Eq. (7) $s_{i j}$ is the lower value of the $j^{\text {th }}$ criterion in the $i^{\text {th }}$ alternative of a solution; $b_{i j}$ - the upper value of the $j$ criterion in the $i$ alternative of a solution; $m$ - the number of evaluation criteria; $n-$ the number of the alternatives compared. After this step, we get the normalized decision making matrix:

$$
\bar{X}=\left[\begin{array}{cccc}
{\left[\overline{s_{11}} ; \overline{b_{11}}\right]} & {\left[\overline{s_{12}} ; \overline{b_{12}}\right]} & \cdots & {\left[\overline{s_{1 m}} ; \overline{b_{1 m}}\right]} \\
{\left[\overline{s_{21}} ; \overline{b_{21}}\right]} & {\left[\overline{s_{22}} ; \overline{b_{22}}\right]} & \cdots & {\left[\overline{s_{2 m}} ; \overline{b_{2 m}}\right]} \\
\vdots & \vdots & \ddots & \vdots \\
\left.\overline{\left[s_{n 1}\right.} ; \overline{b_{n 1}}\right] & {\left[\overline{s_{n 2}} ; \overline{b_{n 2}}\right]} & \cdots & {\left[\overline{s_{n m}} ; \overline{b_{n m}}\right]}
\end{array}\right] .
$$

Step 5. Calculating the weighted normalized decision matrix $X$. The weighted normalized values $x_{i j}$ are calculated as follows:

Here $q_{j}$ is weight of the $j^{\text {th }}$ criterion.

$$
\begin{gathered}
\hat{s_{i j}}=\overline{s_{i j}} \cdot q_{j} ; \\
\hat{b_{i j}}=\overline{b_{i j}} \cdot q_{j} .
\end{gathered}
$$

Then, the weighted normalized decision making matrix is:

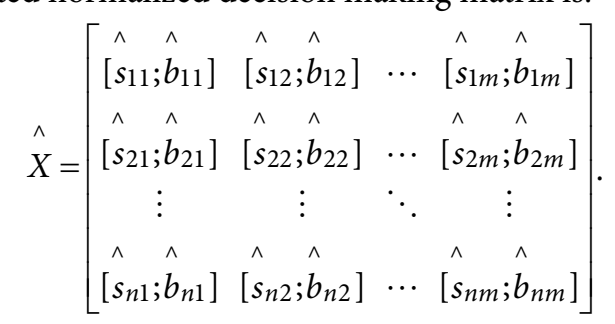

Step 6. Calculating the sums $P_{j}$ of criteria whose larger values are more preferable (i.e. optimization direction is maximization):

$$
\left.P_{j}=\sum_{i=1}^{k} \hat{\left(s_{i j}\right.}+\hat{b}_{i j}\right) / 2 .
$$

In Eq. (11), $k$ is the number of criteria which must be maximized.

Step 7. Calculating the sums $R_{j}$ of criteria whose smaller values are more preferable (i.e. optimization direction is minimization):

$$
\left.R_{j}=\sum_{i=k+1}^{m} \hat{\left(s_{i j}\right.}+\hat{b}_{i j}\right) / 2 ; i=k, \ldots, m .
$$

In Eq. (12), $(m-k)$ is number of criteria which must be minimized. 
Step 8. Determining the minimal value of $R_{j}$ :

$$
R_{\min }=\min _{j} R_{j} ; j=j, \ldots, m
$$

Step 9. Calculating the relative importance of each alternative $Q_{j}$ :

$$
Q_{j}=P_{j}+\frac{\sum_{j=1}^{n} R_{j}}{R_{j} \sum_{j=1}^{n} \frac{1}{R_{j}}} .
$$

Step 10. Determining the optimality criterion $K$ :

$$
K=\max _{j} Q_{j} ; j=1, \ldots, n .
$$

Step 11. Determining the priority order of the alternatives. The greater relative importance of alternative $Q_{j}$, the higher is the priority of the alternative. The relative importance $Q_{j}$ of alternative $j$ indicates the satisfaction degree of the needs of the respondents. In case of $Q_{\max }$, the satisfaction degree is the highest.

Step 12. Calculating the utility degree of each alternative. The utility degree is determined by comparing the analyzed alternatives with the best one. The values of the utility degree are from $0 \%$ to $100 \%$ between the worst and the best alternatives. The utility degree $N_{j}$ of each alternative $j$ is calculated by the equation:

$$
N_{j}=\frac{Q_{j}}{Q_{\max }} \cdot 100 \%,
$$

where $Q_{j}$ and $Q_{\max }$ are the significance of alternatives obtained from Eq. (14).

\section{Evaluation of bank website quality}

\subsection{Conceptual framework}

The primary goal is to utilize a hybrid model in bank website quality evaluation. Furthermore, this hybrid model can be used to compare between the qualities of websites and to identify a path for improvement of a website. Fig. 1 summarizes the proposed hybrid model.

\subsection{Measurement}

The evaluation criteria used in the present study were adapted from the previous web quality studies and its applications. Besides, this study was composed of three main criteria: (a) information quality; (b) service quality; (c) system quality. The first part of the questionnaire included demographic questions such as age, gender, education, income, and occupation. Additionally, there was a table in the second part of the questionnaire that allows respondents pairwise comparisons.

In addition, sub-criteria related to quality of web sites were adapted from the study by DeLone and McLean (2003). These constructs have been well researched, developed, validated and adopted in several previous studies (e.g. Hasan, Abuelrub 2011; Chou, Cheng 2012). 


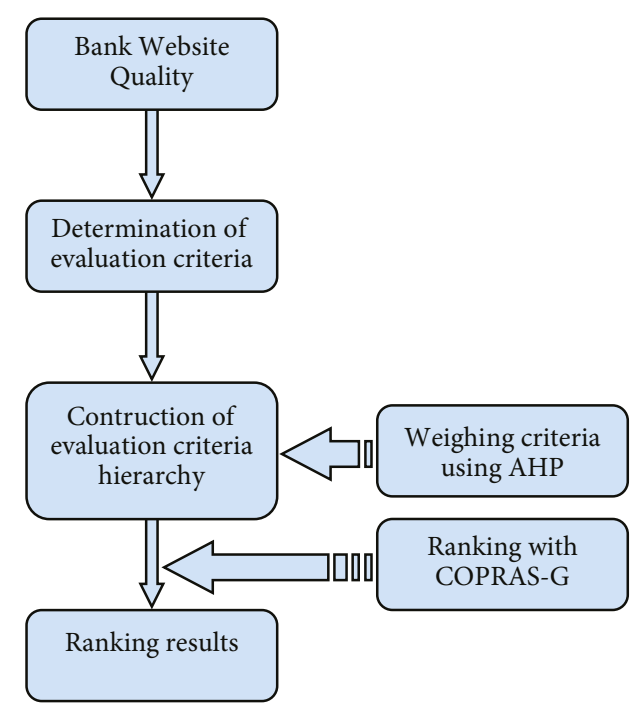

Fig. 1. The proposed hybrid model

\subsection{Sampling}

385 questionnaires were distributed and 364 were returned, which represents a response rate of $94.5 \%$. Furthermore, banking customers as respondents were from one of several kinds of organizations (managers, scientists, owners, teachers, web designers etc.).

Questionnaires were completed in different places around the Afyonkarahisar, Turkey in 2013, during different times of day and on different days during the data collection period. Hence, the resulting sample was well distributed regardless of demographic information. The questionnaire consisted of questions related to possible criteria affecting the quality of bank websites.

\subsection{Data and evaluation criteria selection}

The descriptive statistics of the respondents' demographic characteristics were analyzed and presented in Table 4. According to Table 4, most of the participants were male. Moreover, the majority of the respondents fell into the 3140 year-old age group. They were distributed among a variety of professional industries such as banking, manufacturing, and medicine. Finally, the bulk of the respondents use the online banking platform 45 times per month.

In order to find the prioritization of websites quality criteria for respondents, the best method is to directly ask them. Therefore the 364 respondents were asked to prioritize the three main criteria and their sub-criteria as follows.

- Information quality sub-criteria:

Relevance $x_{1}-\left[s_{i 1} ; b_{i 1}\right]$;

Understandability $x_{2}-\left[s_{i 2} ; b_{i 2}\right]$;

Currency $x_{3}-\left[s_{i 3} ; b_{i 3}\right]$;

Richness $x_{4}-\left[s_{i 4} ; b_{i 4}\right]$; 
- Service quality sub-criteria:

Reliability $x_{5}-\left[s_{i 5} ; b_{i 5}\right]$;

Assurance $x_{6}-\left[s_{i 6} ; b_{i 6}\right]$;

Empathy $x_{7}-\left[s_{i 7} ; b_{i 7}\right]$;

- System quality sub-criteria:

Accessibility $x_{8}-\left[s_{i 8} ; b_{i 8}\right]$;

Navigability $x_{9}-\left[s_{i 9} ; b_{i 9}\right]$;

Response time $x_{10}-\left[s_{i 10} ; b_{i 10}\right]$;

Optimization directions of selected sub-criteria as follows:

$-x_{1}, \ldots, x_{9} \stackrel{\text { optimization direction }}{\longrightarrow} \max$

$-x_{10} \stackrel{\text { optimization direction }}{\longrightarrow} \min$.

Table 4. Demographic characteristics of the respondents

\begin{tabular}{|c|c|c|}
\hline Demographics & Frequency & Percent (\%) \\
\hline $\begin{array}{l}\text { Gender } \\
\text { Male } \\
\text { Female }\end{array}$ & $\begin{array}{l}216 \\
148\end{array}$ & $\begin{array}{l}59.3 \\
40.7\end{array}$ \\
\hline $\begin{array}{l}\text { Age } \\
21-30 \\
31-40 \\
41-50 \\
\text { Over } 50\end{array}$ & $\begin{array}{c}46 \\
244 \\
53 \\
21\end{array}$ & $\begin{array}{c}12.6 \\
67.0 \\
14.6 \\
5.8\end{array}$ \\
\hline $\begin{array}{l}\text { Education } \\
\text { Under high school } \\
\text { University } \\
\text { Masters/PhD }\end{array}$ & $\begin{array}{c}65 \\
281 \\
18\end{array}$ & $\begin{array}{c}17.9 \\
77.2 \\
4.9\end{array}$ \\
\hline $\begin{array}{l}\text { Respondents' industry } \\
\text { Finance } \\
\text { Service } \\
\text { Manufacturing } \\
\text { Others }\end{array}$ & $\begin{array}{c}42 \\
156 \\
78 \\
88 \\
\end{array}$ & $\begin{array}{l}11.5 \\
42.9 \\
21.4 \\
24.2\end{array}$ \\
\hline $\begin{array}{l}\text { Frequency of using online banking (per month) } \\
\text { Less than once } \\
2-3 \text { times } \\
4-5 \text { times } \\
\text { Over } 5 \text { times }\end{array}$ & $\begin{array}{c}24 \\
89 \\
186 \\
65\end{array}$ & $\begin{array}{c}6.6 \\
24.5 \\
51.0 \\
17.9\end{array}$ \\
\hline
\end{tabular}

\subsection{Prioritization criteria for bank websites evaluation}

The aim of using AHP is to determine the weights of the evaluation criteria that will be employed in COPRAS-G method. For pairwise comparison decision making in AHP, a questionnaire was applied to 364 respondents. The paired comparison matrix is one of the matrices that were completed with information of respondents. After the AHP method is used for prioritizing, all comparisons and weighing process are done and the overall weights of each criterion are obtained. By the way, the consistencies for all pairwise comparison matrices were checked with the $C I$ and $C R$ s were found smaller than 0.10 . 
Hence, Fig. 2 shows a graphical plot of the weights. For respondents using bank websites, information quality had the highest weight of 0.539 , followed by system quality (0.298), and service quality (0.163). Additionally, relevance, richness, understandability, navigability, and response time were the top website quality criteria. Empathy, however, had the lowest weight of 0.028. The weights will be used in COPRAS-G method later.

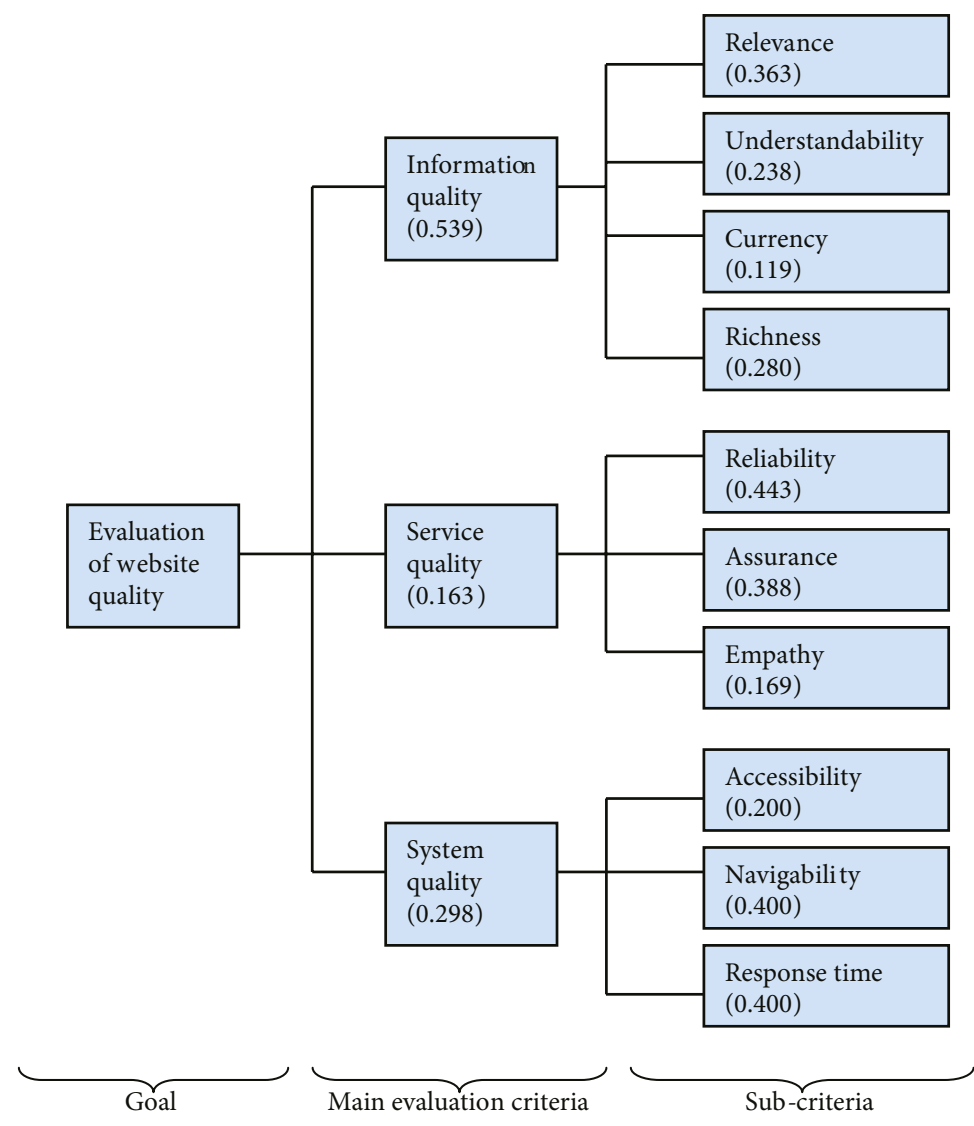

Fig. 2. Weights of main criteria and sub-criteria

\subsection{Evaluation of the bank website quality}

At this stage, respondents evaluated each bank website as to each criterion and then the initial decision matrix (Table 5) developed. The relevant information for the three main criteria and sub-criteria are presented in this table. All sub-criteria are maximizing criteria with the exception of "response time" which is a minimizing sub-criterion. The weights are determined through the AHP method. The values presented in the initial decision matrix are all interval values.

The initial decision making matrix has been normalized first as discussed in Section 2 . The normalized decision making matrix is presented in Table 6 . The weighted decision making matrix presented in Table 7 was constructed next. 


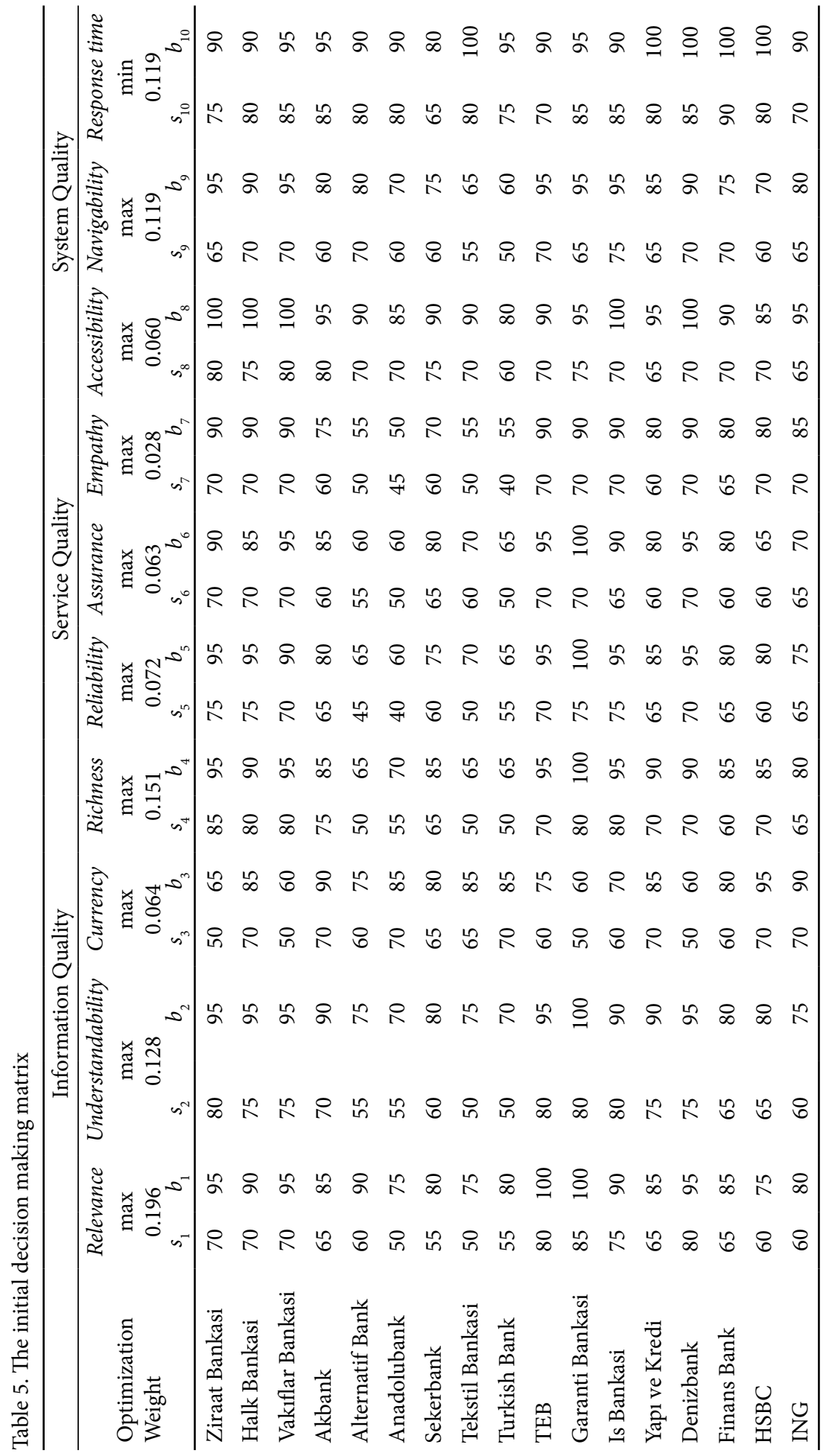




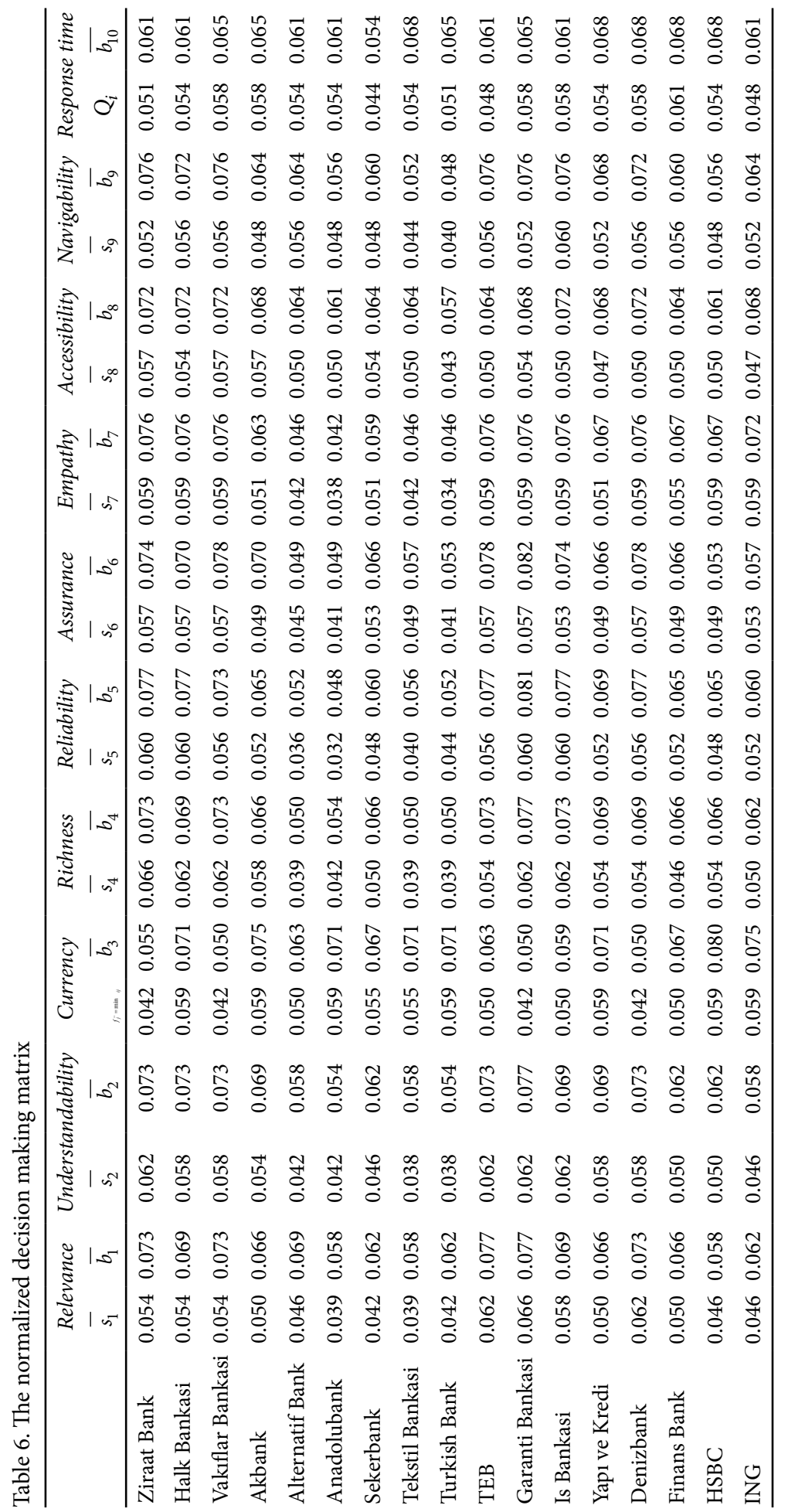




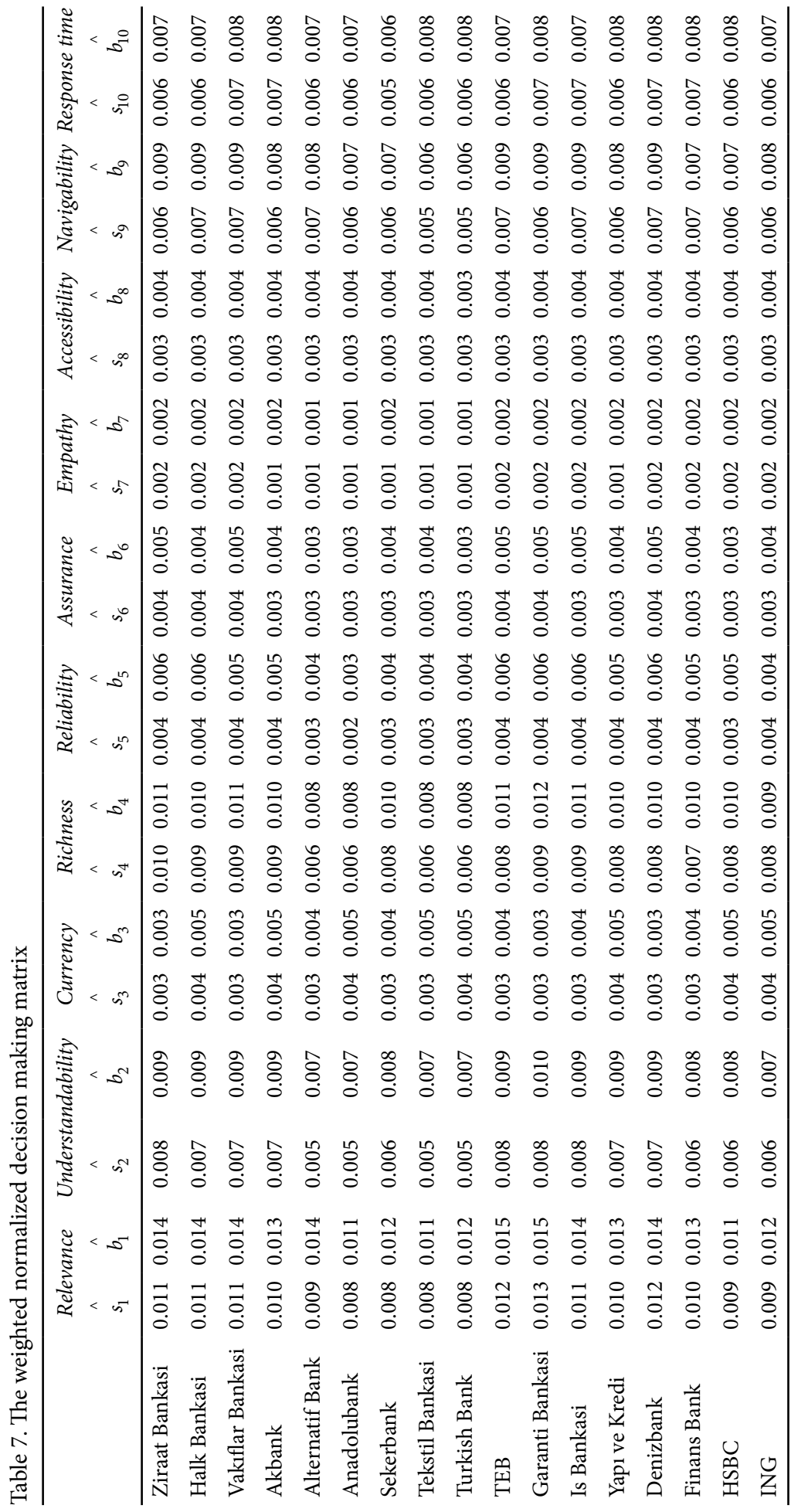


It was followed the procedure described earlier and determined ranking of each alternative by calculating $P_{j}$ using Eq. (11), $R_{j}$ using Eq. (12), and $Q_{j}$ using Eq. (14). Following this step, it was determined the utility degree of each alternative $\left(N_{j}\right)$ using Eq. (16). Table 8 presents the $P_{j}, R_{j}, Q_{j}$, and $N_{j}$ for the seventeen banks under consideration.

Table 8 . The evaluation of the utility degree

\begin{tabular}{lccccc}
\hline & $\begin{array}{c}\text { Optimization } \\
\text { direction is } \\
\text { maximization } \\
P_{j}\end{array}$ & $\begin{array}{c}\text { Optimization } \\
\text { direction is } \\
\text { minimization } \\
R_{j}\end{array}$ & $\begin{array}{c}\text { Banks' } \\
\text { relative } \\
\text { importances } \\
Q_{j}\end{array}$ & $\begin{array}{c}\text { Banks' } \\
\text { utility } \\
\text { degree } \\
N_{j}(\%)\end{array}$ & Rank \\
\hline Ziraat Bankasi & 0.0571 & 0.0067 & 0.0644 & 98.16 & 3 \\
Halk Bankasi & 0.0568 & 0.0069 & 0.0639 & 97.27 & 5 \\
Vakıflar Bankasi & 0.0565 & 0.0073 & 0.0632 & 96.33 & 6 \\
Akbank & 0.0528 & 0.0073 & 0.0595 & 90.68 & 9 \\
Alternatif Bank & 0.0461 & 0.0069 & 0.0532 & 80.98 & 14 \\
Anadolubank & 0.0435 & 0.0069 & 0.0505 & 77.00 & 15 \\
Sekerbank & 0.0489 & 0.0059 & 0.0572 & 87.19 & 11 \\
Tekstil Bankasi & 0.0436 & 0.0073 & 0.0503 & 76.59 & 16 \\
Turkish Bank & 0.0428 & 0.0069 & 0.0499 & 76.02 & 17 \\
TEB & 0.0577 & 0.0065 & 0.0653 & 99.41 & 2 \\
Garanti Bankasi & 0.0590 & 0.0073 & 0.0657 & 100.00 & 1 \\
Is Bankasi & 0.0571 & 0.0071 & 0.0640 & 97.52 & 4 \\
Yapi ve Kredi & 0.0532 & 0.0073 & 0.0599 & 91.20 & 8 \\
Denizbank & 0.0561 & 0.0075 & 0.0626 & 95.41 & 7 \\
Finans Bank & 0.0506 & 0.0077 & 0.0569 & 86.73 & 12 \\
HSBC & 0.0494 & 0.0073 & 0.0561 & 85.47 & 13 \\
ING & 0.0497 & 0.0065 & 0.0573 & 87.22 & 10 \\
\hline
\end{tabular}

As shown in Table 8, Garanti Bankasi with a utility degree of $100 \%$ had the best website regardless of quality in Turkey. TEB with a utility degree of $99.41 \%$ had the second most quality bank website. Ziraat Bankasi with a utility degree of $98.16 \%$ was the third ranking bank website. Finally, Is Bankasi and Halk Bankasi with utility degrees of $97.52 \%$ and $97.27 \%$, respectively, were selected as the fourth and fifth choices for websites. However, Anadolubank, Tekstil Bankasi, and Turkish Bank with utility degrees of 77\%, 76.59\% and 76.02\%, respectively, had the worst websites.

\section{Conclusions}

There are justifiable reasons to evaluate a bank's website quality. For example, a bank's success is more related to the quality of its website. For every bank site, its competitor is only a link away. Hence, a high quality bank website is one that meets its owner's and users' needs.

However, selecting the best quality bank website is a difficult task since this problem is complex with multiple criteria. Hence, this study proposed a hybrid model for evaluating and selecting the best quality bank website. The hybrid model integrates the AHP method 
and the COPRAS-G method. First, the AHP method was used to determine the weights of the website evaluation criteria in this study. Next, the COPRAS-G method was used to rank and select the most quality bank website. Moreover, a real-world case study was presented and demonstrated the applicability of the hybrid model.

The present study investigated factors affecting bank website quality and showed remarkable results. According to the findings, respondents considered information quality as the most important factor. Relevance and richness were highly ranked, indicating that banks should expend more effort to make the website more relevant and rich. Second important factor with regard to the respondents is system quality. Navigability and response time were highly ranked, indicating that banks should expend more effort to make the website more navigable and fast. Interestingly, the relative unimportance of service quality could be a surprising finding. A possible reason is that respondents have experienced poor bank web service. However, this does not mean service quality is less important. Instead, banks might use high service quality as a strategic tool for differentiation from other competitors. Additionally, according to the results of this study, Garanti Bankasi, TEB, and Ziraat Bankasi were the three best bank websites and that Anadolubank, Tekstil Bankasi, and Turkish Bank were the three worst bank websites in Turkey. Therefore, this paper's results had practical implications for the bank managers and owners. By discovering a website's strengths and weaknesses and comparing these to competitors, they can make resource allocation decisions about how to achieve high quality websites.

Finally, the proposed hybrid model has the following advantages: structured and systematic with step-by-step and well-defined procedures; transparent with a comprehensive computation process; logical and rational with a sound mathematical foundation; informative with a scalar value that identifies both the best and the worst bank website simultaneously; and flexibility with the ability to be applied to other MCDM problems.

In sum, the main contribution of this study is to offer bank managers and owners not only investigating factors affecting bank website quality, but also a practical decision tool for assessing website quality. Furthermore, despite this study relates to the banking sector, the hybrid model can also be applied to other sectors to handle any assessment problem. Concerning future research, it would be beneficial to extend this study to a fuzzy environment.

\section{References}

Agarwal, R.; Venkatesh, V. 2002. Assessing a firm's web presence: a heuristic evaluation procedure for the measurement of usability, Information Systems Research 13(2): 168-186.

http://dx.doi.org/10.1287/isre.13.2.168.84

Aghdaie, M. H.; Hashemkhani Zolfani, S.; Zavadskas, E. K. 2013. Market segment evaluation and selection based on application of fuzzy AHP and COPRAS-G methods, Journal of Business Economics and Management 14(1): 213-233. http://dx.doi.org/10.3846/16111699.2012.721392

Ahn, T.; Ryu, S.; Han, I. 2007. The impact of Web quality and playfulness on user acceptance of online retailing, Information \& Management 44(3): 263-275. http://dx.doi.org/10.1016/j.im.2006.12.008

Aladwani, A. M.; Palvia, P. C. 2002. Developing and validating an instrument for measuring user-perceived Web quality, Information \& Management 39(6): 467-476.

http://dx.doi.org/10.1016/S0378-7206(01)00113-6 
Bai, B.; Law, R.; Wen, I. 2008. The impact of website quality on customer satisfaction and purchase intentions: evidence from Chinese online visitors, International Journal of Hospitality Management 27(3): 391-402. http://dx.doi.org/10.1016/j.ijhm.2007.10.008

Baloglu, S.; Pekcan, Y. A. 2006. The website design and internet site marketing practices of upscale and luxury hotels in Turkey, Tourism Management 27(1): 171-176.

http://dx.doi.org/10.1016/j.tourman.2004.07.003

Banaitiene, N.; Banaitis, A.; Kaklauskas, A.; Zavadskas, E. K. 2008. Evaluating the life cycle of a building: a multivariant and multiple criteria approach, Omega: The International Journal of Management Science 36: 429-441.

Barker, T. J.; Zabinsky, Z. B. 2011. A multicriteria decision making model for reverse logistics using analytical hierarchy process, Omega: The International Journal of Management Science 39(5): 558-573. http://dx.doi.org/ 10.1016/j.omega.2010.12.002

Barnes, S. J.; Vidgen, R. 2006. Data triangulation and web quality metrics: a case study in e-government, Information \& Management 43(6): 767-777. http://dx.doi.org/10.1016/j.im.2006.06.001

Barnes, S. J.; Vidgen, R. 2001. An evaluation of cyber-bookshops: the webQual method, International Journal of Electronic Commerce 6: 11-30.

Bauer, H. H.; Hammerschmidt, M.; Falk, T. 2005. Measuring the quality of e-banking portals, International Journal of Bank Marketing 23(2): 153-175. http://dx.doi.org/10.1108/02652320510584395

Bilsel, R. U.; Büyüközkan, G.; Ruan, D. 2006. A fuzzy preference-ranking model for a quality evaluation of hospital web sites, International Journal of Intelligent Systems 21(11): 1181-1197. http://dx.doi.org/10.1002/int.20177

Bindu Madhuri, C.; Anand Chandulal, J.; Padmaja, M. 2010. Selection of best web site by applying COPRAS-G method, International Journal of Computer Science and Information Technologies 1(2): $138-146$.

Bitarafan, M.; Hashemkhani Zolfani, S.; Arefi, S. L.; Zavadskas, E. K. 2012. Evaluating the construction methods of cold-formed steel structures in reconstructing the areas damaged in natural crises, using the methods AHP and COPRAS-G, Archives of Civil and Mechanical Engineering 12(3): 360-367. http://dx.doi.org/10.1016/j.acme.2012.06.015

Büyüközkan, G.; Ruan, D. 2007. Evaluating government websites based on a fuzzy multiple criteria decision-making approach, International Journal of Uncertainty, Fuzziness and Knowledge-Based Systems 15(3): 321-343. http://dx.doi.org/10.1142/S0218488507004704

Büyüközkan, G.; Ruan, D.; Feyzioglu, O. 2007. Evaluating e-learning web site quality in fuzzy environment, International Journal of Intelligent Systems 22(5):567-586. http://dx.doi.org/10.1002/int.20214

Cai, L.; Card, J. A.; Cole, S. T. 2004. Content delivery performance of world wide web sites of US tour operators focusing on destinations in China, Tourism Management 25(2): 219-227. http://dx.doi.org/10.1016/S0261-5177(03)00095-5

Cao, M.; Zhang, Q.; Seydel, J. 2005. B2C e-commerce web site quality: an empirical examination, Industrial Management \& Data Systems 105(5): 645-661. http://dx.doi.org/10.1108/02635570510600000

Carr, R. 2003. Marketing your web site to increase business, The National Public Accountant, September, $11-12$.

Chatterjee, P.; Athawale, V. M.; Chakraborty, S. 2011. Materials selection using complex proportional assessment and evaluation of mixed data methods, Materials and Design 32(2): 851-860. http://dx.doi.org/10.1016/j.matdes.2010.07.010

Chatterjee, P.; Chakraborty, S. 2012. Material selection using preferential ranking methods, Materials and Design 35: 384-393. http://dx.doi.org/10.1016/j.matdes.2011.09.027

Cheng, R. W.; Chin, T. L.; Pei, H. T. 2010. Evaluating business performance of wealth management banks, European Journal of Operational Research 207(2): 971-979. http://dx.doi.org/10.1016/j.ejor.2010.04.034 
Chiou, W. C.; Lin, C. C.; Perng, C. 2010. A strategic framework for website evaluation based on a review of the literature from 1995-2006, Information \& Management 47(5-6): 282-290.

http://dx.doi.org/10.1016/j.im.2010.06.002

Chou, W. C.; Cheng, Y. P. 2012. A hybrid fuzzy MCDM approach for evaluating website quality of professional accounting firms, Expert Systems with Applications 39(3): 2783-2793. http://dx.doi.org/10.1016/j.eswa.2011.08.138

Datta, S.; Beriha, G. S.; Patnaik, B.; Mahapatra, S. S. 2009. Use of compromise ranking method for supervisor selection: a multi criteria decision making (MCDM) approach, International Journal of Vocational and Technical Education 1(1): 713.

DeLone, W. H.; McLean, E. R. 2003. The DeLone and McLean model of information systems success: a ten-year update, Journal of Management Information Systems (19): 9-30.

DeLone, W. H.; McLean, E. R. 2004. Measuring e-commerce success: applying the DeLone \& McLean information systems success model, International Journal of Electronic Commerce 9(1): 31-47.

Deng, J. 1982. Control problems of grey systems, Systems and Control Letters 5: 288-294.

Deng, J. L. 1988. Properties of relational space for grey system, in Deng, J. L. (Ed.). In Essential Topics on Grey System-Theory and Applications. Beijing: China Ocean. 113 p.

Ecer, F.; Küçük, O. 2008. Tedarikçi seçiminde analitik hiyerarşi yöntemi ve bir uygulama, Atatürk Üniversitesi Sosyal Bilimler Enstitüsü Dergisi 11(1): 355-369.

Figueira, J.; Greco, S.; Ehrgott, M. (Eds.). 2005. Multiple criteria decision analysis: state of the art surveys. Boston: Springer. $1048 \mathrm{p}$.

Gao, L.; Hailu, A. 2013. Identifying preferred management options: an integrated agent-based recreational fishing simulation model with an AHP-TOPSIS evaluation method, Ecological Modelling 249: 7583. http://dx.doi.org/10.1016/j.ecolmodel.2012.07.002

Ginevičius, R.; Podvezko, V. 2008. Multicriteria evaluation of Lithuanian banks from the perspective of their reliability for clients, Journal of Business Economics and Management 9(4): 257-267. http://dx.doi.org/ 10.3846/bm.2010.133

Gregg, D. G.; Walczak, S. 2010. The relationship between website quality, trust and price premiums at online auctions, Electronic Commerce Research 10(1): 125. http://dx.doi.org/ 10.1007/s10660-010-9044-2

Hasan, L.; Abuelrub, E. 2011. Assessing the quality of web sites, Applied Computing and Informatics 9(1): 11-29. http://dx.doi.org/10.1016/j.aci.2009.03.001

Hashemkhani Zolfani, S.; Rezaeiniya, N.; Aghdaie, M. H.; Zavadskas, E. K. 2012a. Quality control manager selection based on AHP-COPRAS-G methods: a case in Iran, Ekonomska Istrazivanja - Economic Research 25(1): 88-104.

Hashemkhani Zolfani, S.; Chen, I. S.; Rezaeiniya, N.; Tamosaitiene, J. 2012b. A hybrid MCDM model encompassing AHP and COPRAS-G methods for selecting company supplier in Iran, Technological and Economic Development of Economy 18(3): 529-543. http://dx.doi.org/10.3846/20294913.2012.709472

Huang, S. J.; Chiu, N. H.; Chen, L. W. 2008. Integration of the grey relational analysis with genetic algorithm for software effort estimation, European Journal of Operational Research 188(3): 898-909. http://dx.doi.org/ 10.1016/j.ejor.2007.07.002

Hur, Y.; Ko, Y. J.; Valacich, J. 2011. A structural model of the relationships between sport website quality, e-satisfaction, and e-loyalty, Journal of Sport Management 3: 458-473.

Hwang, C. L.; Yoon, K. 1981. Multiple attribute decision making: a state of the art survey, Lecture Notes in Economics and Mathematical Systems. Berlin: Springer-Verlag. 269 p. http://dx.doi.org/10.1007/978-3-642-48318-9

Islam, A.; Tsuji, K. 2011. Evaluation of usage of university websites in Bangladesh, Journal of Library \& Information Technology 31(6): 469-479. 
Iwaarden, J. V.; Wiele, T. V. D.; Ball, L.; Millen, R. 2004. Perceptions about the quality of web sites: a survey amongst students at Northeastern University and Erasmus University, Information \& Management 41(8): 947-959. http://dx.doi.org/10.1016/j.im.2003.10.002

Jayawardhena, C. 2004. Measurement of service quality in internet banking: the development of an instrument, Journal of Marketing Management 20: 185-207. http://dx.doi.org/ 10.1362/026725704773041177

Jun, M.; Cai, S. 2001. The key determinants of internet banking service quality: a content analysis, International Journal of Bank Marketing 19(7): 276-291. http://dx.doi.org/10.1108/02652320110409825

Kaklauskas, A.; Zavadskas, E. K.; Raslanas, S.; Ginevicius, R.; Komka, A.; Malinauskas, P. 2006. Selection of low-e windows in multiple criteria methods COPRAS: a Lithuanian case, Energy and Buildings 38(5): 454-462. http://dx.doi.org/10.1016/j.enbuild.2005.08.005

Kasli, M.; Avcikurt, C. 2008. An investigation to evaluate the websites of tourism departments of universities in Turkey, Journal of Hospitality, Leisure, Sport and Tourism Education 7(2): 77-92. http://dx.doi.org/ 10.3794/johlste.72.194

Kaya, T.; Kahraman, C. 2011, A fuzzy approach to e-banking website quality assessment based on integrated AHP-ELECTRE method, Technological and Economic Development of Economy 17(2):313-334. http://dx.doi.org/10.3846/20294913.2011.583727

Kim, S.; Stoel, L. 2004. Dimensional hierarchy of retail website quality, Information \& Management 41(5): 619-633. http://dx.doi.org/10.1016/j.im.2003.07.002

Koufaris, M. 2002. Applying the technology acceptance model and flow theory to online customer behavior, Information Systems Research 13(2): 205-223. http://dx.doi.org/ 10.1287/isre.13.2.205.83

Law, R. 2007. A fuzzy multiple criteria decision-making model for evaluating travel websites, Asia Pacific Journal of Tourism Research 12(2): 147-159. http://dx.doi.org/10.1080/10941660701243372

Lee, K. C.; Chung, N. 2009. Understanding factors affecting trust in and satisfaction with mobile banking in Korea: a modified DeLone and McLean's model perspective, Interacting with Computers 21(5-6): 385-392. http://dx.doi.org/10.1016/j.intcom.2009.06.004

Lee, K. W.; Tsai, M. T.; Maria, C. L. L. 2011. From marketplace to marketspace: investigating the consumer switch to online banking, Electronic Commerce Research and Applications 10(1): 115-125. http://dx.doi.org/10.1016/j.elerap.2010.08.005

Lee, Y.; Kozar, K. 2006. Investigating the effect of website quality on e-business success: an analytic hierarchy process (AHP) approach, Decision Support Systems 42(3): 1383-1401. http://dx.doi.org/10.1016/j.dss.2005.11.005

Liang, C. J.; Chen, H. J. 2009. A study of the impacts of website quality on customer relationship performance, Total Quality Management 20(9): 971-988. http://dx.doi.org/10.1080/14783360903181784

Liu, C.; Arnett, K. P. 2000. Exploring the factors associated with web site success in the context of electronic commerce, Information Management 38(1): 23-33. http://dx.doi.org/10.1016/S0378-7206(00)00049-5

Loiacono, E. T.; Chen, D. Q.; Goodhue, D. L. 2002. WebQualk revisited: predicting the intent to reuse a website, in Proc. of 8th Americas Conference on Information Systems, August 2002, Dallas, TX, USA, 301-309.

Loiacono, E. T.; Richard, T. W.; Dale, L. G. 2007. WebQual: an instrument for consumer evaluation of web sites, International Journal of Electronic Commerce 11(3): 51-87. http://dx.doi.org/10.2753/JEC1086-4415110302

Madu, C. N.; Madu, A. A. 2002. Dimensions of e-quality, International Journal of Quality and Reliability Management 19(3): 246-258. http://dx.doi.org/10.1108/02656710210415668

Miranda-González, F. J.; Bañegil-Palacios, T. M. 2004. Quantitative evaluation of commercial web sites: an empirical study of Spanish firms, International Journal of Information Management 24(4):313-328. http://dx.doi.org/10.1016/j.ijinfomgt.2004.04.009 
Mittal, H.; Sharma, M.; Mittal, J. P. 2012. Analysis and modelling of websites quality using fuzzy technique, Second International Conference on Advanced Computing \& Communication Technologies, 7-8 January 2012, Rohtak, Haryana, 1015. http://dx.doi.org/10.1109/ACCT.2012.25

Mohanty, R. P.; Seth, D.; Mukadam, S. 2007. Quality dimensions of e-commerce and their implications, Total Quality Management 18(3): 219-247. http://dx.doi.org/10.1080/14783360601149992

Moustakis, V.; Tsironis, L.; Litos, C. 2006. A model of website quality assessment, The Quality Management Journal 13(2): 22-37.

Negash, S.; Ryan, T.; Igbaria, M. 2003. Quality and effectiveness in web-based customer support system, Information \& Management 40(8): 757-768. http://dx.doi.org/10.1016/S0378-7206(02)00101-5

Palmer, J. W. 2002. Website usability, design and performance metrics, Information Systems Research 13(2): 151-167. http://dx.doi.org/ 10.1287/isre.13.2.151.88

Podvezko, V. 2011. The Comparative Analysis of MCDA Methods SAW and COPRAS, Inzinerine Ekonomika - Engineering Economics 22(2): 134-146. http://dx.doi.org/10.5755/j01.ee.22.2.310

Ranganathan, C.; Ganapathy, S. 2002. Key dimensions of business-to-consumer Web sites, Information Management 39(6): 457-465. http://dx.doi.org/10.1016/S0378-7206(01)00112-4

Rolland, S.; Freeman, I. 2010. A new measure of e-service quality in France, International Journal of Retail \& Distribution Management 38(7): 497-517. http://dx.doi.org/10.1108/09590551011052106

Roxas, M. L.; Peek, L.; Peek, G.; Hagemann, T. 2000. A preliminary evaluation of professional accounting services: direct marketing on the Internet, Journal of Service Marketing 14(7): 595-606. http://dx.doi.org/10.1108/08876040010352763

Saaty, T. L. 1980. The analytic hierarchy process. New York: McGraw Hill. 287 p.

Sahu, N. K.; Datta, S.; Mahapatra, S. S. 2012. Establishing green supplier appraisement platform using grey concepts, Grey Systems: Theory and Application 2(3): 395-418.

Shee, D. Y.; Wang, Y. S. 2008. Multi-criteria evaluation of the web-based e-learning system: a methodology based on learner satisfaction and its applications, Computers \& Education 50(3): 894-905. http://dx.doi.org/10.1016/j.compedu.2006.09.005

Smith, G. 2001. Applying evaluation criteria to New Zealand government websites, International Journal of Information Management 21(2): 137-149. http://dx.doi.org/10.1016/S0268-4012(01)00006-8

Sun, C. C.; Lin, G. T. R. 2009. Using fuzzy TOPSIS method for evaluating the competitive advantages of shopping websites, Expert Systems with Applications 36(9): 11764-11771. http://dx.doi.org/10.1016/j.eswa.2009.04.017

Swaid, S. I.; Wigand, R. T. 2009. Measuring the quality of e-service: scale development and initial validation, Journal of Electronic Commerce Research 10(1): 13-28.

Tavana, M.; Momeni, E.; Rezaeiniya, N.; Mirhedayatian, S. M.; Rezaeiniya, H. 2013. A novel hybrid social media platform selection model using fuzzy ANP and COPRAS-G, Expert Systems with Applications 40(14): 5694-5702. http://dx.doi.org/10.1016/j.eswa.2013.05.015

Torkzadeh, G.; Dhillon, G. 2002. Measuring factors that influence the success of Internet commerce, Information Systems Research 13(2): 87-204. http://dx.doi.org/10.1287/isre.13.2.187.87

Tsai, W. H.; Chou, W. C.; Lai, C. W. 2010. An effective evaluation model and improvement analysis for national parks websites: a case study of Taiwan, Tourism Management 31(6): 936-952. http://dx.doi.org/10.1016/j.tourman.2010.01.016

Turskis, Z.; Zavadskas, E. K.; Peldschus, F. 2009. Multi-criteria optimization system for decision making in construction design and management, Inzinerine Ekonomika -Engineering Economics 1: 7-17.

Viteikiene, M.; Zavadskas, E. K. 2007. Evaluating the sustainability of Vilnius city residential areas, Journal of Civil Engineering and Management 13(2): 149-155.

http://dx.doi.org/10.1080/13923730.2007.9636431 
Wan, C. S. 2002. The web sites of international tourist hotels and tour wholesalers in Taiwan, Tourism Management 23(2): 155-160. http://dx.doi.org/10.1016/S0261-5177(01)00048-6

Webb, H. W.; Webb, L. A. 2004. SiteQual: an integrated measure of web site quality, Journal of Enterprise Information Management 17(6): 430-440. http://dx.doi.org/10.1108/17410390410566724

Wu, F.; Mahajan, V.; Balasubramanian, S. 2003. An analysis of e-business adoption and its impact on business performance, Journal of the Academy of Marketing Science 31(4): 425-447. http://dx.doi.org/10.1177/0092070303255379

Yang, Z.; Cai, S.; Zhou, Z.; Zhou, N. 2005. Development and validation of an instrument to measure user perceived service quality of information presenting Web portals, Information \& Management 42(4): 575-589. http://dx.doi.org/10.1016/S0378-7206(04)00073-4

Yu, X.; Guo, S.; Guo, J.; Huang, X. 2011. Rank B2C e-commerce websites in alliance based on AHP and fuzzy TOPSIS, Expert Systems with Applications 38(4): 3550-3557. http://dx.doi.org/10.1016/j.eswa.2010.08.143

Zavadskas, E. K.; Kaklauskas, A.; Sarka, V. 1994. The new method of multicriteria complex proportional assessment of projects, Technological and Economic Development of Economy 1(3): 131-139.

Zavadskas, E. K.; Kaklauskas, A.; Turskis, Z.; Tamosaitiene, J. 2008. Selection of the effective dwelling house walls by applying attributes values determined at intervals, Journal of Civil Engineering and Management 14(2): 85-93. http://dx.doi.org/10.3846/1392-3730.2008.14.3

Zavadskas, E. K.; Turskis, Z. 2011. Multiple criteria decision making (MCDM) methods in economics: an overview, Technological and Economic Development of Economy 17(2): 397-427. http://dx.doi.org/10.3846/20294913.2011.593291

Zech, C.; Wagner, W.; West, R. 2013. The effective design of church web sites: extending the consumer evaluation of web sites to the non-profit sector, Information Systems Management 30(2): 92-99. http://dx.doi.org/10.1080/10580530.2013.773800

Zeithaml, V. A. 2002. Service excellence in electronic channels, Managing Service Quality 12(3): 135-138. http://dx.doi.org/10.1108/09604520210429187

Zhou, T.; Lu, Y.; Wang, B. 2009. The relative importance of website design quality and service quality in determining consumers' online repurchase behavior, Information Systems Management 26(4): 327-337. http://dx.doi.org/10.1080/10580530903245663

Zopounidis, C.; Doumpos, M. 2002. Multi-criteria decision aid in financial decision making: methodologies and literature review, Journal of Multi-Criteria Decision Analysis 11(4-5): 167-186. http://dx.doi.org/10.1002/mcda.333

Fatih ECER is an Assistant Professor of Operations Research in the International Trade and Finance, Faculty of Economics and Business Administrations, University of Afyon Kocatepe, Turkey. He holds a BSc in Mathematics from Dokuz Eylul University, Izmir, Turkey, and a MSc and PhD in Business Administrations from University of Afyon Kocatepe, Turkey. His work has been published, or is forthcoming, in high quality international journals. His current research interests are in the Multiple Criteria Decision Making (MCDM), optimization, Artificial Neural Networks (ANNs), and data mining. 